\title{
"Humanized Robots": A Proposition of Categories to Understand Virtual Influencers
}

\author{
Antonio Batista da Silva Oliveira \\ Federal University of Rio de Janeiro, Brazil \\ antonio.batista@coppead.ufrj.br
}

\section{Paula Chimenti}

Federal University of Rio de Janeiro, Brazil

\section{Abstract}

Worldwide investments in influencer marketing are growing and could reach US\$ 101 billion in 2020. But how can the brands shield themselves from scandals and other limitations of human influencers? The solution for many companies has involved robots. Virtual influencers (VI) are virtual robots that can emulate human appearance and behaviour and have become a trend in marketing. This study analyses how non-human influencers affect marketing communication by adopting two methods that are unpublished in the investigation of this phenomenon: a systematic literature review and netnography in conjunction with in-depth interviews with specialists resulting in the study identifying five categories (two of which are unpublished and unexplored in the literature) that can facilitate management decisions and also future studies around VIs: anthropomorphism/humanization, attractiveness, authenticity, scalability, and controllability. This study also identified more convergences than divergences between the virtual and the real and between humans and non-humans, generating challenges, opportunities, and guidelines for future research and for assisting management in making decisions concerning digital marketing.

Keywords: virtual influencers, digital marketing, exploratory study, artificial intelligence, robots, virtualization

\section{Introduction}

There was an estimated turnover of more than US\$ 101 billion in 2020 in the influencer marketing industry (Association of National Advertisers, 2018) with investments in marketing using artificial intelligence growing, including the development of virtual influencers (VIs). Spark Capital, for example, led a US\$ 125 million investment round in Brud, the start-up that created the world's first VI, Lil Miquela (Alexander, 2019). For many, "virtual influencers are the future of advertising, fashion and commerce" (Robinson, 2020, p. 3). In fact, influencers who are involved in scandals, harming advertisers and partners, may have their days numbered. There is already a good number of virtual humanoid robots (virtual influencers) in campaigns for global brands such as Prada, Samsung, Porsche, Unilever, Calvin Klein, Ikea, and KFC. Some VIs requested by global advertisers such as Miquela (@lilmiquela), Shudu (@shudu), and Imma (@imma.gram), were designed realistically using computer generated images (CGI) or other resources. There is, however, a lot of fog over the origin and functioning of VIs with many people calling them AI influencers, while others are confused by their realism and ask, "Is it human or not?". In Miquela's case, after months of speculation about her identity, she replied, "I am a robot." The "revelation" took place in 2018. Miquela has a realistic image and a rich "life story" as a singer and model. She interacts with followers, creates content, makes advertisements, etc., but all of this exists only on the virtual plane. Miquela has 
more than 7 million followers on different social networks (Instagram, TikTok, Facebook, and YouTube). She stars in campaigns for major brands, music releases, and was even voted one of the 25 most influential people on the internet by Time magazine in 2018 alongside personalities such as former President Donald Trump.

Although there are VIs that are not very realistic, this study will focus on those that challenge the boundaries between the real and the virtual, the human and the non-human. VIs are operated largely by humans, but machine learning, self-supervision, language, and other attributes of artificial intelligence have developed rapidly in recent years with the Natural Language Generation (NLG) model growing by 1 billion parameters to 17 billion in just one year (Microsoft, 2020). Therefore, this study addresses managerial and practical implications around VIs such as the reduction in relevance of human influencers, more controllable options for advertisers, greater investments in artificial intelligence, and the construction of humanized virtual robots.

From a theoretical point of view, while graphics, narratives, and artificial intelligence are enriching the VI phenomenon in marketing (Alexander, 2019), there is little literature on nonhuman influencers in digital marketing with the explanatory and prescriptive capacity of the field being predominantly focused on human influence. Many recent studies deal exclusively with the influence between humans (Boerman, 2020; Silva et al., 2020; Torres et al., 2019; Jiménez-Castillo \& Sánchez-Fernández, 2019; Ashman et al., 2018) with some citing nonhuman/virtual influencers as a trend (Appel et al., 2020; Kádeková \& Holienčinová, 2018), but only two recent studies (Robinson, 2020; Moustakas et al., 2020) deal specifically with VIs. We add to these studies the original perspective of consumers, answering a call from both Robinson (2020) and Moustakas et al. (2020).

This study aims to bring an initial understanding of the VI phenomenon, contribute to filling the gap in non-human influencers, and to answer the question: How do non-human influencers affect marketing communication? To answer this question, the study adopts two methods that are unpublished in the investigation of this phenomenon: a systematic literature review and netnography in conjunction with in-depth interviews with specialists. With this the study identified five categories (two of which are unpublished and unexplored in the literature) that can facilitate management decisions and also future studies around VIs: anthropomorphism/ humanization, attractiveness, authenticity, scalability, and controllability. In addition, the study found that in the eyes of many humans, non-human characters are not part of a narrative or message. To paraphrase McLuhan and Fiore (1967), "the non-human is the message".

\section{Literature review}

A systematic literature review was performed to understand the state-of-the art of research on non-human influencers.

The databases Scopus, JSTOR, EBSCO, and Google Scholar were used to search for the keywords "virtual influencer" (VI) and "CGI influencer" (CGI, an acronym for computer generated images). The keywords "virtual influencer" and "CGI influencer" prevail in commercial (Emma, 2018) and academic (Appel et al., 2020) materials. A keyword research was carried out prioritizing titles and abstracts of articles from any areas of knowledge. Due to the initial scarcity of results (as shown in table 1), the keyword "digital influencer" (DI) was added due to the synergy with the main theme while making a comparability between humans 
and non-humans for subsidizing possible theories applicable to the phenomenon. Initially (step 1), 897 results were identified considering the aforementioned keywords and all areas of knowledge. Then (step 2), only peer-reviewed articles were selected, returning 176 results. Finally (step 3), only articles written in English were kept, leaving 32 articles, which are summarized in Table 1 and analysed in the following sections in line with the objectives of this study.

\begin{tabular}{|c|c|c|c|c|}
\hline Authors & Theory & $\begin{array}{l}\text { Approach/ } \\
\text { Method }\end{array}$ & $\begin{array}{l}\text { Categories identified } \\
\text { in each study }\end{array}$ & $\begin{array}{l}\text { Relationship of the theme or context } \\
\text { with human or non-human influencers }\end{array}$ \\
\hline $\begin{array}{l}\text { Robinson, } \\
2020\end{array}$ & $\begin{array}{c}\text { Agency } \\
\text { Theory and } \\
\text { Personal } \\
\text { Identity }\end{array}$ & $\begin{array}{c}\text { Qualitative/ } \\
\text { Essay }\end{array}$ & $\begin{array}{l}\text { attractiveness } \\
\text { authenticity } \\
\text { controllability }\end{array}$ & Non-human \\
\hline $\begin{array}{l}\text { Moustakas } \\
\text { et al., } 2020\end{array}$ & $\begin{array}{l}\text { Parasocial } \\
\text { Interaction }\end{array}$ & $\begin{array}{c}\text { Qualitative/s } \\
\text { emi- } \\
\text { structured } \\
\text { interviews }\end{array}$ & $\begin{array}{l}\text { attractiveness } \\
\text { authenticity } \\
\text { controllability }\end{array}$ & Non-human \\
\hline $\begin{array}{c}\text { Appel et al., } \\
2020\end{array}$ & N/A & $\begin{array}{c}\text { Qualitative/ } \\
\text { Systematic } \\
\text { review }\end{array}$ & $\begin{array}{l}\text { attractiveness } \\
\text { authenticity } \\
\text { controllability }\end{array}$ & Human* \\
\hline $\begin{array}{l}\text { Marôpo et } \\
\text { al., } 2020\end{array}$ & $\begin{array}{c}\text { Cultural } \\
\text { Intermediation }\end{array}$ & $\begin{array}{c}\text { Qualitative/ } \\
\text { Content } \\
\text { analysis }\end{array}$ & $\begin{array}{l}\text { attractiveness } \\
\text { authenticity }\end{array}$ & Human \\
\hline $\begin{array}{l}\text { Boerman, } \\
2020\end{array}$ & $\begin{array}{l}\text { Parasocial } \\
\text { Interaction }\end{array}$ & $\begin{array}{c}\text { Quantitative } \\
\text { /Hypothesis } \\
\text { testing based } \\
\text { on online } \\
\text { experiment }\end{array}$ & $\begin{array}{l}\text { attractiveness } \\
\text { authenticity }\end{array}$ & Human \\
\hline $\begin{array}{c}\text { Casaló et al., } \\
2020\end{array}$ & N/A & $\begin{array}{c}\text { Quantitative } \\
\text { / Likert scale } \\
\text { for theory } \\
\text { test } \\
\end{array}$ & $\begin{array}{l}\text { attractiveness } \\
\text { authenticity }\end{array}$ & Human \\
\hline $\begin{array}{l}\text { Silva et al., } \\
\quad 2020\end{array}$ & $\begin{array}{l}\text { Consumer } \\
\text { Behaviour }\end{array}$ & $\begin{array}{c}\text { Qualitative/ } \\
\text { Semiotic } \\
\text { images and } \\
\text { critical } \\
\text { incident } \\
\text { technique }\end{array}$ & $\begin{array}{l}\text { attractiveness } \\
\text { authenticity } \\
\text { controllability }\end{array}$ & Human \\
\hline $\begin{array}{c}\text { Guerreiro et } \\
\text { al., } 2019\end{array}$ & N/A & $\begin{array}{l}\text { Quantitative } \\
\text { /T test, } \\
\text { simple } \\
\text { frequency, } \\
\text { etc. }\end{array}$ & $\begin{array}{l}\text { authenticity } \\
\text { controllability }\end{array}$ & Human \\
\hline $\begin{array}{c}\text { Gillpatrick et } \\
\text { al., } 2019\end{array}$ & $\begin{array}{c}\text { Consumer } \\
\text { Value Chain } \\
(\mathrm{CVC})\end{array}$ & $\begin{array}{c}\text { Qualitative/ } \\
\text { Essay }\end{array}$ & N/A & Human ${ }^{* *}$ \\
\hline $\begin{array}{l}\text { Gillpatrick, } \\
2019\end{array}$ & $\begin{array}{c}\text { Consumer } \\
\text { Value Chain } \\
\text { (CVC) }\end{array}$ & $\begin{array}{c}\text { Qualitative/ } \\
\text { Essay }\end{array}$ & $\begin{array}{l}\text { attractiveness } \\
\text { controllability }\end{array}$ & Human $^{* *}$ \\
\hline
\end{tabular}




\begin{tabular}{|c|c|c|c|c|}
\hline $\begin{array}{c}\text { Hutchinson, } \\
2019\end{array}$ & $\begin{array}{c}\text { Cultural } \\
\text { Intermediation }\end{array}$ & $\begin{array}{c}\text { Qualitative/ } \\
\text { Ethnograph } \\
\mathrm{y}\end{array}$ & $\begin{array}{l}\text { attractiveness } \\
\text { authenticity } \\
\text { controllability }\end{array}$ & Human $^{* *}$ \\
\hline $\begin{array}{l}\text { Miranda et } \\
\text { al., } 2019\end{array}$ & $\begin{array}{c}\text { Perceived } \\
\text { usefulness, } \\
\text { Perceptual } \\
\text { homophily, } \\
\text { TRA, and } \\
\text { Theory of } \\
\text { planned } \\
\text { behaviour }\end{array}$ & $\begin{array}{c}\text { Quantitative } \\
\text { / Structural } \\
\text { equation } \\
\text { modelling }\end{array}$ & $\begin{array}{l}\text { attractiveness } \\
\text { authenticity } \\
\text { controllability }\end{array}$ & Human \\
\hline $\begin{array}{l}\text { Jiménez- } \\
\text { Castillo \& } \\
\text { Sánchez } \\
\text { Fernández, } \\
2019\end{array}$ & $\begin{array}{c}\text { Media } \\
\text { Dependency } \\
\text { Theory }\end{array}$ & $\begin{array}{c}\text { Quantitative } \\
\text { / Semantic } \\
\text { evaluation / } \\
\text { Opinion } \\
\text { using Likert } \\
\text { scale }\end{array}$ & $\begin{array}{l}\text { attractiveness } \\
\text { authenticity } \\
\text { controllability }\end{array}$ & Human \\
\hline $\begin{array}{c}\text { Verdoodt \& } \\
\text { Feci, } 2019\end{array}$ & $\begin{array}{c}\text { Social } \\
\text { Comparison } \\
\text { Theory } \\
\end{array}$ & $\begin{array}{c}\text { Qualitative/ } \\
\text { Content } \\
\text { analysis }\end{array}$ & $\begin{array}{c}\text { authenticity } \\
\text { controllability }\end{array}$ & Human \\
\hline $\begin{array}{l}\text { Dobreva et } \\
\text { al., } 2019\end{array}$ & $\begin{array}{l}\text { Theory of } \\
\text { Cognitive } \\
\text { Dissonance }\end{array}$ & $\begin{array}{c}\text { Mixed/Conte } \\
\text { nt analysis } \\
\text { and network } \\
\text { analysis }\end{array}$ & $\begin{array}{c}\text { authenticity } \\
\text { controllability }\end{array}$ & Human** \\
\hline Moura, 2019 & N/A & $\begin{array}{c}\text { Quantitative } \\
\text { / Survy with } \\
\text { Likert scale }\end{array}$ & controllability & Human \\
\hline $\begin{array}{l}\text { Kuksov \& } \\
\text { Liao, } 2019\end{array}$ & Game Theory & $\begin{array}{c}\text { Quantitative } \\
\text { / Experiment } \\
\text { with } \\
\text { consumers } \\
\text { followed by } \\
\text { Bayesian } \\
\text { analysis }\end{array}$ & $\begin{array}{c}\text { authenticity } \\
\text { controllability }\end{array}$ & Human \\
\hline $\begin{array}{c}\text { Torres et al., } \\
2019\end{array}$ & $\begin{array}{l}\text { Meaning } \\
\text { transfer }\end{array}$ & $\begin{array}{c}\text { Quantitative } \\
\text { / Structural } \\
\text { equation } \\
\text { model }\end{array}$ & $\begin{array}{l}\text { attractiveness } \\
\text { authenticity } \\
\text { controllability }\end{array}$ & Human \\
\hline $\begin{array}{c}\text { Kádeková \& } \\
\text { Holienčinov } \\
\text { á, } 2018\end{array}$ & $\begin{array}{l}\text { Consumer } \\
\text { Behaviour }\end{array}$ & $\begin{array}{c}\text { Quantitative } \\
\text { / Statistical } \\
\text { processing } \\
\text { and } \\
\text { hypothesis } \\
\text { Testing }\end{array}$ & $\begin{array}{l}\text { attractiveness } \\
\text { authenticity } \\
\text { controllability }\end{array}$ & Human* \\
\hline $\begin{array}{c}\text { Carvalho, } \\
2018\end{array}$ & $\begin{array}{l}\text { Consumer } \\
\text { Behaviour }\end{array}$ & $\begin{array}{l}\text { Quantitative } \\
\text { / Forms, } \\
\text { simple } \\
\text { frequency, } \\
\text { etc. }\end{array}$ & $\begin{array}{l}\text { attractiveness } \\
\text { authenticity } \\
\text { controllability }\end{array}$ & Human \\
\hline
\end{tabular}




\begin{tabular}{|c|c|c|c|c|}
\hline $\begin{array}{l}\text { Drenten et } \\
\text { al., } 2018\end{array}$ & N/A & $\begin{array}{c}\text { Qualitative/ } \\
\text { Content } \\
\text { analysis }\end{array}$ & $\begin{array}{l}\text { attractiveness } \\
\text { authenticity } \\
\text { controllability }\end{array}$ & Human \\
\hline Goanta, 2018 & N/A & $\begin{array}{l}\text { Qualitative/ } \\
\text { Case studies }\end{array}$ & $\begin{array}{l}\text { attractiveness } \\
\text { authenticity } \\
\text { controllability }\end{array}$ & Human \\
\hline $\begin{array}{l}\text { Jorge et al., } \\
2018\end{array}$ & $\begin{array}{l}\text { Media } \\
\text { Literacy }\end{array}$ & $\begin{array}{c}\text { Qualitative/ } \\
\text { Content } \\
\text { analysis }\end{array}$ & $\begin{array}{l}\text { attractiveness } \\
\text { authenticity } \\
\text { controllability }\end{array}$ & Human \\
\hline $\begin{array}{c}\text { Aran- } \\
\text { Ramspott et } \\
\text { al., } 2018\end{array}$ & $\begin{array}{c}\text { Cultural } \\
\text { Studies / } \\
\text { Theory of } \\
\text { Uses and } \\
\text { Gratifications }\end{array}$ & $\begin{array}{c}\text { Mixed/Anal } \\
\text { ysis of } \\
\text { audience via } \\
\text { Survey and } \\
\text { Focus } \\
\text { groups } \\
\end{array}$ & $\begin{array}{l}\text { attractiveness } \\
\text { authenticity } \\
\text { controllability }\end{array}$ & Human \\
\hline $\begin{array}{l}\text { Ashman et } \\
\text { al., } 2018\end{array}$ & $\begin{array}{c}\text { Technologies } \\
\text { of the Self }\end{array}$ & $\begin{array}{c}\text { Qualitative/ } \\
\text { Netnograph } \\
\mathrm{y}\end{array}$ & $\begin{array}{c}\text { attractiveness } \\
\text { authenticity } \\
\text { controllability }\end{array}$ & Human \\
\hline $\begin{array}{l}\text { Graziano \& } \\
\text { Perez, } 2018\end{array}$ & $\begin{array}{l}\text { Network } \\
\text { Society and } \\
\text { Stakeholder }\end{array}$ & $\begin{array}{c}\text { Qualitative/ } \\
\text { Semi- } \\
\text { structured } \\
\text { in-depth } \\
\text { interviews } \\
\text { and } \\
\text { Content } \\
\text { analysis } \\
\end{array}$ & controllability & Human \\
\hline $\begin{array}{c}\text { Gross \& von } \\
\text { Wangenhei } \\
\text { m, } 2018\end{array}$ & $\begin{array}{c}\text { Social } \\
\text { Presence }\end{array}$ & $\begin{array}{c}\text { Qualitative/I } \\
\text { nterviews e } \\
\text { Content } \\
\text { analysis }\end{array}$ & $\begin{array}{l}\text { attractiveness } \\
\text { authenticity } \\
\text { controllability }\end{array}$ & Human \\
\hline Maden, 2018 & $\begin{array}{l}\text { Diffusion of } \\
\text { Innovations }\end{array}$ & $\begin{array}{c}\text { Quantitative } \\
\text { Q } \\
\text { Quantitative } \\
\text { content } \\
\text { analysis, } \\
\text { simple } \\
\text { frequency, } \\
\text { etc. }\end{array}$ & $\begin{array}{l}\text { attractiveness } \\
\text { authenticity } \\
\text { controllability }\end{array}$ & Human \\
\hline Cotter, 2018 & $\begin{array}{c}\text { Social Field } \\
\text { Theory }\end{array}$ & $\begin{array}{c}\text { Qualitative/ } \\
\text { Content } \\
\text { analysis }\end{array}$ & $\begin{array}{l}\text { authenticity } \\
\text { controllability }\end{array}$ & Human** \\
\hline $\begin{array}{c}\text { Clifford \& } \\
\text { Verdoodt, } \\
2017 \\
\end{array}$ & N/A & $\begin{array}{c}\text { Qualitative/ } \\
\text { Content } \\
\text { analysis } \\
\end{array}$ & $\begin{array}{l}\text { attractiveness } \\
\text { authenticity } \\
\text { controllability }\end{array}$ & Human \\
\hline $\begin{array}{c}\text { Vinerean, } \\
2017 \\
\end{array}$ & N/A & $\begin{array}{c}\text { Qualitative/ } \\
\text { SLR }\end{array}$ & $\begin{array}{c}\text { attractiveness } \\
\text { authenticity }\end{array}$ & Human \\
\hline $\begin{array}{c}\text { Edgerton et } \\
\text { al., } 2016\end{array}$ & $\begin{array}{c}\text { Media } \\
\text { Richness }\end{array}$ & $\begin{array}{c}\text { Mixed/Cont } \\
\text { ent analysis } \\
\text { and }\end{array}$ & $\begin{array}{l}\text { authenticity } \\
\text { controllability }\end{array}$ & Human \\
\hline
\end{tabular}




\begin{tabular}{|c|c|c|c|c|}
\hline & $\begin{array}{c}\text { quantitative } \\
\text { indexing }\end{array}$ & Human \\
\hline $\begin{array}{c}\text { Archer \& } \\
\text { Harrigan, } \\
2016\end{array}$ & N/A & $\begin{array}{c}\text { Qualitative/I } \\
\text { nterviews } \\
\text { and } \\
\text { ethnography }\end{array}$ & controllability & Human \\
\hline $\begin{array}{c}\text { Golder \& } \\
\text { Macy, 2014 }\end{array}$ & N/A & $\begin{array}{c}\text { Qualitative/ } \\
\text { Literature } \\
\text { review }\end{array}$ & $\begin{array}{c}\text { authenticity } \\
\text { controllability }\end{array}$ & Hon \\
\hline
\end{tabular}

Table 1. Overview of the systematic literature review and the presence of VIs in the literature on influencers marketing.

* Mention VIs, but they are not the main topic of the study.

** Mention non-human elements such as algorithms and artificial intelligence, but not VIs.

The literature review carried out in this study and presented in Table 1 identified that regarding influence marketing, 30 of the 34 studies deal only with human influencers and 2 focus humans but mention VIs in some way. Only two studies out of the 34 have non-human influencers as their main theme. Despite the strong predominance of studies on human influencers, there appears to be a recent growth trend in research on non-human influencers (notably VIs) with one paper citing the phenomenon of VIs in 2018 (Kádeková \& Holienčinová, 2018) and three papers citing the theme in 2020 (Appel et al., 2020; Robinson, 2020; Moustakas et al., 2020), two of which (Robinson, 2020; Moustakas et al., 2020) dedicated entirely to VIs.

\subsection{Concept and types of influencers}

"Influencer marketing" is seen as a new frontier of opportunities due to be "one of the fastest growing tools in terms of getting new customers online" (Kádeková \& Holienčinová, 2018, p. 92). Despite this, there is still a strong need for studies on digital influencers and the consequences of their influence and opinion leadership (Casaló et al., 2020; Jiménez-Castillo \& Sánchez-Fernández, 2019). There are also interesting studies involving cultural intermediation (Marôpo et al., 2020; Hutchinson, 2019), health communication (Edgerton et al., 2016), "Soft Facts" (Dobreva et al., 2019), e-commerce (Moura, 2019), opinion leadership (Kuksov \& Liao, 2019), sexualization/attention economics (Drenten et al., 2018), competition dynamics/neoliberalism (Ashman et al., 2018), eWOM (Vinerean, 2017), motivation (Archer \& Harrigan, 2016), and social/privacy research (Golder \& Macy, 2014).

Kádeková and Holienčinová (2018) define an influencer as an individual with a significant number of followers on social networks and who is paid by brands to promote products to those followers. Boerman (2020) classifies influencers by the number of followers, but there are other classifications (Gross \& von Wangenheim, 2018), although the number of followers appears to be dominant. In any case, an ever-present element is authenticity. It is linked to honesty, reliability, credibility, and transparency (Miranda et al., 2019; Guerreiro et al., 2019; Maden, 2018; Jorge et al., 2018; Carvalho, 2018).

As for VIs, Appel et al. (2020, p. 89) mention that "there are cases where consumers know they are interacting with bots and seem not to care" and recommend future research on whether there would be any difference between virtual and real influencers in their effect on consumers. Robinson (2020, p. 1) states that "there is nothing morally significant that distinguishes them from natural 'real life' influencers", and the debate is just beginning. 
Attractiveness is another factor linked to influencers (Torres et al., 2019). Moustakas et al. (2020) prescribes the construction of a strong and engaging personality to humanize VIs. This would include "conflicts, aspirations, and challenges" and would help to expand "affective bonds" with followers. Therefore, a greater attractiveness of the robot would be to look even less...like a robot. Appel et al. (2020, p. 90) ask: "What is the underlying appeal of virtual influencers?". The question remains unanswered, while Kádeková and Holienčinová (2018, p. 97) question whether it would be the case to replace human influencers with virtual "realists and intrigues". But they emphasize that the commercial and legal aspects are some of the factors at stake.

Non-human influencers are not new, but they have been changing and growing. The literature focuses on algorithms (Hutchinson, 2019; Cotter, 2018) or on artificial and robotic intelligence and on recommendation systems (Gillpatrick, 2019; Gillpatrick et al., 2019; Graziano \& Perez, 2018). In fact, most studies on digital influence and/or digital marketing focus on relationships between humans and disregard a unit of analysis: non-human influencers.

The studies in this review involve fields such as information technology, marketing, information systems, psychology, law, education, and sociology. Although necessary, such studies seem insufficient to understand the new phenomenon of virtual influencers.

This study partly considers thoughts from the field of psychology such as the Theory of Social Comparison (Miller \& Dollard, 1941) and the Parasocial Theory, while pointing out a relevant gap. According to the Parasocial Theory (Horton \& Wohl, 1956), fans have a unilateral relationship with celebrities that involves equally unilateral and illusory affective dimensions, which seems applicable to the relationships between influencers and followers, but recent studies (Bond, 2016) in the context of social networks deal only with relationships between humans. The Theory of Social Comparison (Miller \& Dollard, 1941) argues that people tend to compare themselves to others and to copy certain models with comparison and imitation being important elements of social learning. Both theories focus on relationships between humans, but with the growth of non-human influencers, the gap persists in the face of nonhuman actors.

The present study advances some aspects of the discussion on VIs: it is the first to use a systematic literature review and a netnography to address the theme. It is also a pioneer in the approach of the consumer's vision (via netnography) and establishes that the human avatar (VI) beyond being only equal to the human, as Robinson stated (2020), may also be even superior in some respects. And going beyond what Moustakas et al. (2020) pointed out, VIs seem to be something more than a marketing strategy, so this study organizes and proposes for the first time five categories that can support management decisions and future studies involving VIs: anthropomorphism/humanization, scalability, attractiveness, authenticity, and controllability.

\section{Research method}

The literature review identified a gap regarding the understanding of non-human influencers in general and particularly on the view and behaviour of the consumer of this type of influencer. In fact, the option here to analyse VI consumers/followers was in response to requests from literature (Robinson, 2020; Moustakas et al., 2020), which was done through netnography. 
As it is a relatively recent phenomenon, this is a qualitative exploratory study (Creswell, 2007) combining interviews with specialists and netnography (Kozinets, 2002). This study, due to its exploratory and qualitative design, does not intend to produce generalizations nor correlations between variables, but it does aim to provide the foundations for future theoretical generalizations. The practice of interviewing a small number of sources (especially experts through in-depth interviews) is recurrent in works of different themes and fields (see Kautz et al., 2020; Hasan \& Linger, 2020; Moustakas et al., 2020).

Eight specialists participated in semi-structured interviewees with some of them being among the main executives in Brazil working in relevant organizations in the media, research, and marketing segments. The interviewees are professionals who have participated or are participating in innovative actions involving influencers from different niches such as cosmetics, sports, media, children \& youth audiences, research, and games. They operate predominantly in Brazil, which is the second country in the world in average daily access time to social networks (GlobalWebIndex, 2019) and the 2nd largest worldwide audience for virtual influencers (HypeAuditor, 2019). Table 2 presents a summary of the interviewees' profiles.

\begin{tabular}{|c|c|c|c|c|c|}
\hline $\begin{array}{c}\text { Interviewee/ } \\
\text { Expert }\end{array}$ & Age & Generation & Gender & $\begin{array}{l}\text { School } \\
\text { Training }\end{array}$ & Occupation \\
\hline Interviewee 1 & $\begin{array}{c}40-50 \\
\text { years old }\end{array}$ & $x$ & male & Masters & $\begin{array}{l}\text { Entrepreneur in digital marketing and } \\
\text { marketing executive nominated for national } \\
\text { awards and cofounder of important brands in } \\
\text { the digital environment }\end{array}$ \\
\hline Interviewee 2 & $\begin{array}{c}20-30 \\
\text { years old }\end{array}$ & $\mathrm{Y}$ & female & $\begin{array}{c}\text { BA } \\
\text { Degree }\end{array}$ & $\begin{array}{l}\text { Culture and consumption researcher with } \\
\text { emphasis on influencers }\end{array}$ \\
\hline Interviewee 3 & $\begin{array}{c}20-30 \\
\text { years old }\end{array}$ & Y & female & $\begin{array}{c}\text { BA } \\
\text { Degree }\end{array}$ & $\begin{array}{l}\text { Commercial project manager on an innovative } \\
\text { platform that brings together influencers }\end{array}$ \\
\hline Interviewee 4 & $\begin{array}{c}20-30 \\
\text { years old }\end{array}$ & $\mathrm{Y}$ & male & $\begin{array}{c}\text { BA } \\
\text { Degree }\end{array}$ & $\begin{array}{l}\text { Digital marketing entrepreneur and partner } \\
\text { manager }\end{array}$ \\
\hline Interviewee 5 & $\begin{array}{c}40-50 \\
\text { years old }\end{array}$ & $x$ & male & MBA & Social media executive on a TV station \\
\hline Interviewee 6 & $\begin{array}{c}40-50 \\
\text { years old }\end{array}$ & $x$ & male & $\begin{array}{l}\text { Doctorate } \\
\text { degree }\end{array}$ & $\begin{array}{l}\text { Entrepreneur in digital marketing and trade } \\
\text { association director }\end{array}$ \\
\hline Interviewee 7 & $\begin{array}{c}20-30 \\
\text { years old }\end{array}$ & Y & female & Masters & $\begin{array}{l}\text { Influencer in a channel with over } 10 \text { million } \\
\text { followers }\end{array}$ \\
\hline Interviewee 8 & $\begin{array}{c}30-40 \\
\text { years old }\end{array}$ & Y & male & $\begin{array}{l}\text { High } \\
\text { School }\end{array}$ & $\begin{array}{l}\text { Entrepreneur and director in digital marketing } \\
\text { agency }\end{array}$ \\
\hline
\end{tabular}

Table 2. Summary profile of the interviewed agents and experts

The interviews were based on a script prepared via a literature review, giving interviewees freedom (semi-structured model) so that they could produce insights and opinions that were not covered in the literature. The audios of the eight interviews were recorded with an average duration of 61.25 minutes (total of 490 minutes). The recordings were transcribed by a specialized professional service that generated 114 pages of text.

In addition, a 10-month netnography was carried out (Kozinets, 2002; Belk, R., Fisher, E., \& Kozinets, 2013; Kozinets \& Nocker, 2018; Kozinets, 2019) involving the profiles of the Top Five 
existing VIs (HypeAuditor, 2019) with a focus on the interactions between these VIs and their followers. In addition to the theme itself (VIs), the use of netnography in this article is a way of seeking to "break barriers" (MacInnis et al., 2020) in research involving consumers. Netnography is defined as a "particular kind of online ethnography whose use is commonplace in marketing, consumer research, tourism, and many other kinds of academic business and communication research fields" (Kozinets, 2019, p. 69). Netnography seeks to "affirm the preeminence of the construction of meaning and its understanding, providing a cultural approach to study the social interaction that transpires through interactive media" (Kozinets \& Nocker, 2018, p. 131). Netnography is one of the differentials of this study in relation to the few articles that deal with VIs so far and meets the suggestion of Robinson (2020) and Moustakas et al. (2020) to investigate VI consumers or followers.

The VIs were selected according to the ranking of the main VIs on Instagram (HypeAuditor, 2019). The top five at the time were Miquela, Noonoouri, Imma, Shudu, and Bermuda. Noonoouri was excluded from the analysis as he is the only non-humanoid and therefore not the focus of this study. All posts and interactions of the four VIs were analysed. Posts with photos, texts, and/or videos were followed up and analysed daily for ten months (January to October 2020), except for Stories, which last only 24 hours. For the purposes of this study, each post was considered as unique data, but some posts may have more than one "page", which may contain different photos or texts on each "page" of the post, for example. Therefore, the number of photos and videos tends to be even greater than that presented in this study, if the other "pages" of each post were to be considered separately. Table 3 presents a summary of the data analyzed in the interviews and netnography:

\begin{tabular}{|l|l|}
\hline \multicolumn{1}{|c|}{ Data source } & \multicolumn{1}{c|}{ Quantity of saved/analysed data } \\
\hline Posts & 497 \\
\hline Videos & 66 of 497 \\
\hline Comments & 387,107 \\
\hline $\begin{array}{l}\text { In-depth interviews with digital } \\
\text { marketing experts }(\mathrm{n}=8)\end{array}$ & 490 audio recording minutes \\
\hline $\begin{array}{l}\text { Monitored profiles }(\mathrm{n}=4) \text { and total } \\
\text { number of followers }\end{array}$ & 114 single-spaced 11 pt-font printed pages \\
\hline Duration of data collection & January 2020 to October 2020 (10 months) \\
\hline
\end{tabular}

Table 3: Dataset Details

As for the profiles analysed on netnography, all are open to the public, with no restrictions on access to posts. The profiles chosen are shown in Table 4 with the links of each VI and the links of the respective operators:

\begin{tabular}{|c|l|l|l|l|l|}
\hline No. & \multicolumn{1}{|c|}{$@$ name } & \multicolumn{2}{c|}{$\begin{array}{c}\text { Number of followers } \\
(2019 \text { and 2020) }\end{array}$} & \multicolumn{1}{c|}{ Country } & Operator \\
\hline 1 & Lilmiquela & $1.7 \mathrm{M}$ & $2.8 \mathrm{M}$ & United States & Brud \\
\hline 3 & Imma.gram & $159 \mathrm{~K}$ & $320 \mathrm{~K}$ & Japan & aww.tokyo \\
\hline 4 & Shudu.gram & $192 \mathrm{~K}$ & $209 \mathrm{~K}$ & England & TheDiigitals \\
\hline 5 & Bermudaisbae & $180 \mathrm{~K}$ & $285 \mathrm{~K}$ & United States & Brud \\
\hline
\end{tabular}

Table 4. VIs studied on netnography

Source: adapted by the authors based on HypeAuditor, 2019 
The transcripts of the interviews as well as the netnography content were subjected to analysis through inductive research and interpretive procedures (Miles, Huberman, and Saldaña, 2014) as a way of identifying patterns. The categories were identified and developed in meetings between the authors, which generated the five categories proposed in this study, as illustrated in the results and discussion section of this study.

\section{Results and discussion}

This section is organized according to the five categories that emerged from the literature, interviews, and netnography. Three of the categories have been previously identified in the literature and although initially applicable to human-influencers appeared in our field as also relevant for nonhuman influencers, which are attractiveness, authenticity, and controllability. Two of the categories emerged from the interviews and netnography and are original propositions of this study, which are scalability and anthropomorphism/humanization.

\subsection{Attractiveness}

Attractiveness is related to the influencer's (physical and/or behavioural) appeal to followers, as well as to the commercial dimension, endorsement, and congruence with the brand (Torres et al., 2019). Some aspects of attractiveness are presented by interviewees and netnography:

As much as I am still in the "league" of human influencers, looking at the brand, hiring (...) this is one of the great advantages: these [virtual] influencers do not suffer human and physical limitations. (Interviewee 3)

Attractiveness is inherent to influence, while certainly being necessary to have some real or apparent attraction such as talent, beauty, style, comedy, sensuality, or authority to attract attention. It is also possible that attractiveness occurs due to attributes such as value creation, novelty, exclusivity, among others. In addition, attractiveness can connect with other categories. It seems plausible that strong attractiveness contributes to more intense scalability, for example.

Attractiveness can be promoted, for example, through beauty, which is a certain artistic sense (Moustakas et al., 2020) or some aesthetic appeal, as in the case of the smartphone ad where the VI Imma (Figure 1) receives several praises for her beauty, as well as praise for the beauty of the advertisement as a whole. Criticism and questioning almost do not exist in the ad, reinforcing the idea that authenticity can lose space for attractiveness or other appeals (Imma "does not exist" to the point of being able to "use" the smartphone, for example). This is the same case as Miquela, a virtual robot (VI) who appears singing in a video and, although receiving criticism, seems to be praised by most followers, who even register the beauty of Miquela's "voice".

However, as with human influencers, VIs do not live only by praise: some of the interviewees in this study see an "unattainable perfection" in VIs and point out risks to the mental health of some followers due to unattainable comparisons. A follower questioned a post by Shudu accusing the creators of the profile of investing in an "unreal" beauty standard. Even so, most of the reactions seemed complimentary with some followers even defending Shudu. In turn, Bermuda caused comparisons of several followers who wanted to have the beauty of this VI or who felt less beautiful than Bermuda. Female followers generally seem to highlight the 
beauty of Bermuda and some of the male followers point to the VI's sensuality. The ice cream that Bermuda would be "enjoying" almost disappears in the discussion.
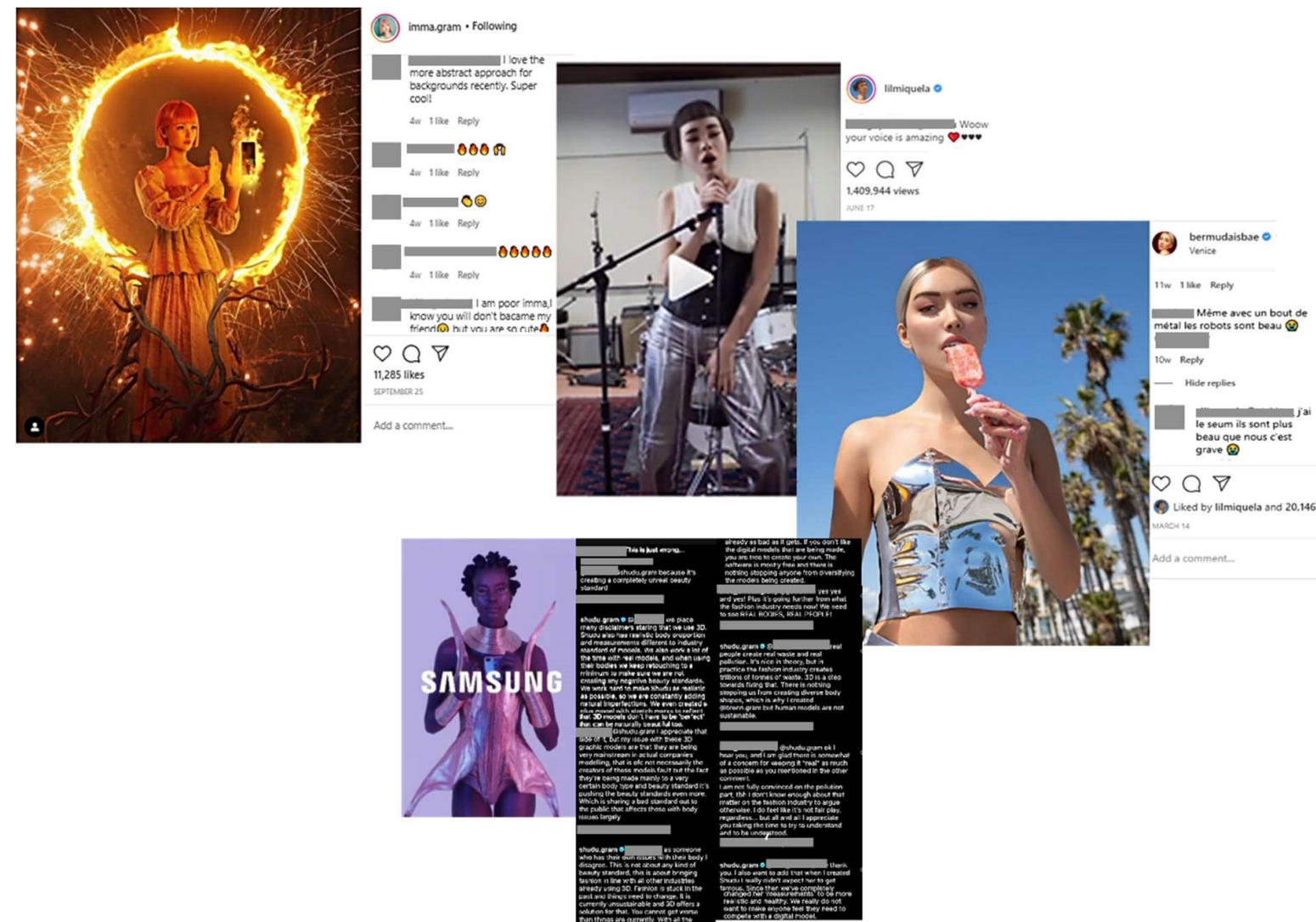

$\bigcirc \bigcirc \nabla$

Figure 1. From left to right clockwise (examples of VIs):

Imma (www.instagram.com/p/CFjTQsNjcBl/) in an ad campaign; Miquela (www.instagram.com/p/ CBii1RynIvo/) singing in a video; Shudu (www.instagram.com/p/CEuLEJ1hSnv/) campaigning for Samsung and receiving criticism in another post for having an "unreal" beauty standard; Bermuda (www.instagram.com/p/B9ulbrAhfFp/) "eating" ice cream.

There are few mentions of algorithms, artificial intelligence, or authenticity in the posts, even though they are virtual robots that are eating an ice cream, for example. However, if the algorithms and the virtual dimension itself can help in the performance of the VI, certainly an advanced graphic and a very engaging narrative facilitate the engagement in general, generating feedback between attractiveness and scalability. Likewise, a powerful algorithm for a mediocre narrative does not seem to be a perfect effectiveness, which brings up the possible connection with another category: authenticity. In fact, algorithms determine user behaviour, but they do not do it unilaterally (Cotter, 2018). Attractiveness can be related and increased with fascination, curiosity, or other factors and can be simply non-linear:

Faced with the account of a strong human drama by a virtual influencer, I think I have a prejudiced view. Perhaps because I have little knowledge of the subject. But I think it would make me weird, not that I would stop following, I think it would even be a curiosity, maybe. (...) Maybe I love one of these too... I don't know. (Interviewee 7)

According to our research, attractiveness is an important aspect to understand digital influencers and it remains important when moving to world VIs. 


\subsection{Authenticity}

Authenticity connects with trust, reliability, and transparency. It refers to the influencer's relationship with his followers and the influencer's narrative coherence and nexus between influencer and advertisers (Torres et al., 2019). It may be related to feelings on both sides (influencer and follower), although sometimes a model of parasocial relationship seems to prevail or the illusion in the follower that $s /$ he has intimacy with the influencer. In this sense, the respondents' considerations are consistent with the literature (Appel et al., 2020; Marôpo et al., 2020):

I look very authentically at a traditional influencer. (...) It could be that we start to do this with artificial intelligence too, right? (Interviewee 1)

The more feelings of truth the virtual influencer has, the closer we will be to an ideal model of influencers. (Interviewee 4)

Consistent with the Social Comparison Theory (Miller \& Dollard, 1941), there are those who believe that VIs could harm people: "In relation to the robot, (...) it is a perfection that nobody can achieve, so it goes into disrepute. It is a speech that to me sounds empty, is very idealized, not feasible. For some subjects it can be, while for others it is not" (Interviewee 6).

However, the authenticity and ethics of VIs do not seem to be linked to what would be "plausible" in a linear logic. Arguments such as "virtual robots don't really exist and therefore cannot be authentic as a human" seem to be challenged in many situations. Below are some examples in Figure 2.

It is no use looking at the phenomenon of VIs simply with the logic of previous phenomena. Example: "only physical or biological beings can taste an ice cream". Well, Magnum/Unilever, one of the world's largest ice cream brands, hired Imma as its first virtual ambassador. In the post in which Imma announces the commercial partnership with Magnum (Figure 2), most followers, many of them aware that Imma is a virtual robot, show joy and few are the questions about the validity of a virtual being becoming an ambassador of an ice cream. There are many demonstrations of affection for Imma's "victory", even if that victory seems to some people to be absurd. Examples are becoming more complex: Cameron-James Wilson, the creator of Shudu, is accused of being a white man who exploits a black profile to make a profit. In parallel, many accolades are directed to Shudu's beauty by other followers. It is curious to point out that Trevor McFedries, co-founder, and CEO of Brud, the start-up that created Miquela (before Shudu, inclusive) is a black man who maintains VIs of different types, including a white VI (Bermuda). It is difficult to identify the real level of authenticity of the profiles, if any, in a debate like this. Although relevant, the discussion about control, ownership, and authenticity does not usually dominate the profiles of VIs and seems to lack greater maturity. And it seems that there are more decisive elements with the power of the narrative being one of them.

Bermuda laments that she cannot "see friends" because of the social distancing during the Covid-19 pandemic, and although many praise the sensuality of the photo or Bermuda's text that has warmer complements, the posture of some followers focuses on the fact that Bermuda could not be contaminated by the coronavirus because she is a robot. It is curious to note that Miquela, when saying that she is "working hard" to help artists during the same pandemic, does not receive questions. Miquela appears painting a wall, which is hardly plausible (why 
do they criticize and claim that a virtual being could not be touched by a virus but applaud when a virtual being decides to paint walls?).

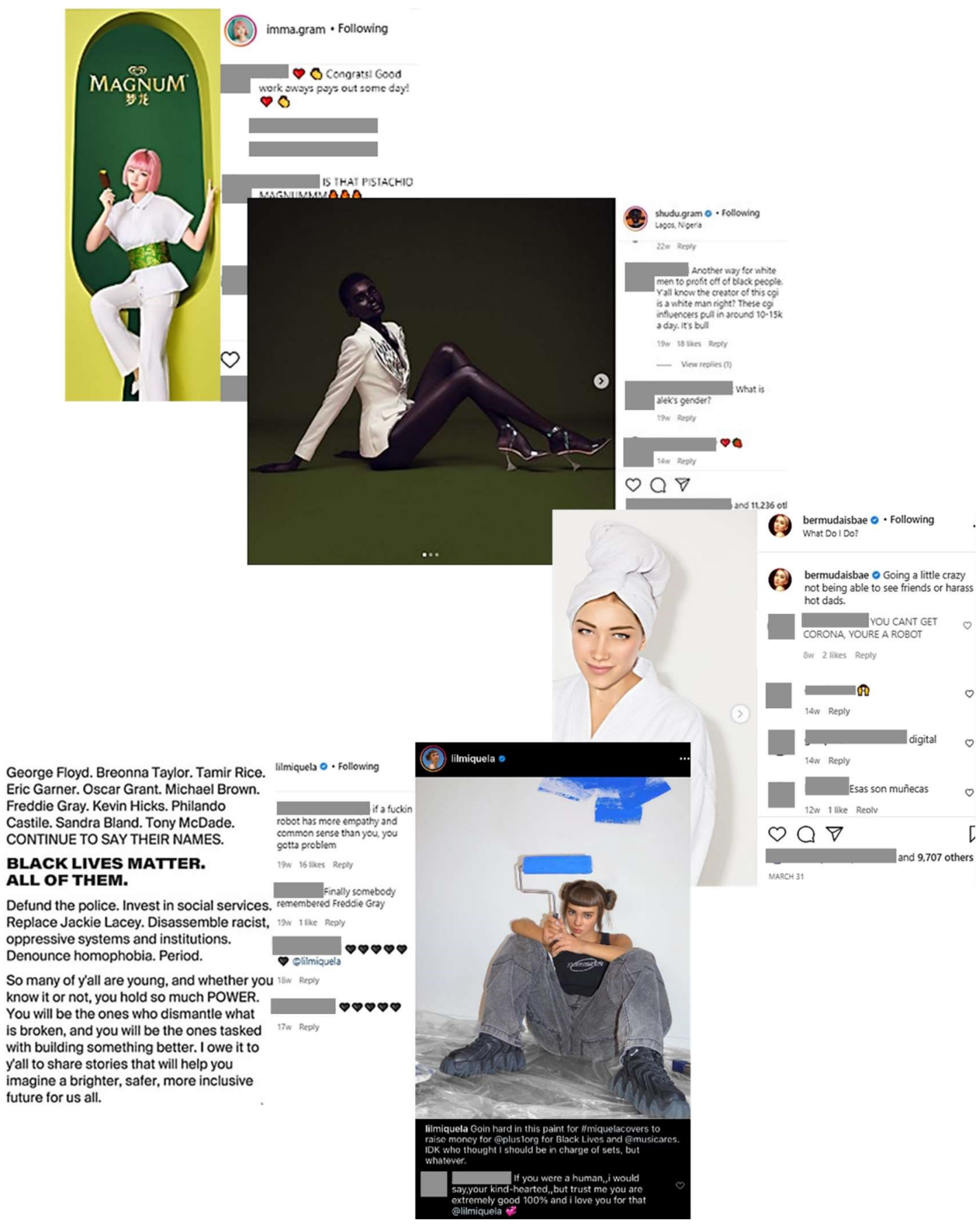

Figure 2. From left to right clockwise:

Imma (www.instagram.com/p/B_W6yPojjk5/) in a Magnum ice cream campaign;

Shudu (www.instagram.com/ p/B7eGv1ehpIN/), "the world's first digital supermodel"; Bermuda (www.instagram.com/p/BaPOHYDXZX/) upset by "not being able to see friends" during social distancing during the Covid-19 pandemic; Miquela (www.instagram.com/p/CBbXVDSn8T3/ and www.instagram.com/p/CBRjULXHaxZ/) "striving" to help artists during social distancing during the Covid-19 pandemic and supporting the "Black Lives Matter" movement a few days after George Floyd's death, in addition to asking to report homophobia. 
In another post, Miquela defends the "Black Lives Matter" campaign and asks them to fight against racism and homophobia. Few questions and a huge support network surround the post. Miquela's narrative in those posts (more humanistic and less sensual than Bermuda during the pandemic seems to eliminate many facts: Bermuda was the one who "revealed" that Miquela was in fact a VI and part of the "most intimate" circle of Miquela as Miquela and Bermuda belong to the same owner, a masterful creativity start-up called Brud. Miquela and Bermuda are both VIs and therefore share the same nature in terms of possibilities and limitations. But the narratives of Miquela and Bermuda are different. Authenticity, therefore, although it has some relevance, does not seem to be the focus. In the post on Black Lives Matter, a follower goes on to say that "if someone has less empathy than a robot, that person has a problem." Would Miquela be more human than many flesh and blood beings? In a post in which Miquela seeks to raise donations to help artists and other audiences, a follower says that "If you were a human, I would say that you have a good heart, but believe me, you are extremely good $100 \%$ [sic] and I love you for that". The power of the narrative, along with other elements, not only reduces the relevance of authenticity, but at times it is the authenticity of humans that is questioned by the VI followers.

In addition to all the above, one of the effects that virtual and/or non-human beings can generate is trust. Appel et al. (2020, p. 89), point out that therapy robots "because they are explicitly nonhuman, are perceived as less critical and can therefore be easier to be trusted by users." As for Vis, another type of robot, one of the interviewees in this study opines:

I think that the virtual influencer is a type of influence that starts to have an expectation for authenticity a little higher than the human influencer. (Interviewee 2)

And there are those who suggest a path opposite to that pointed out by most of the literature:

We don't have to arrive trying to educate. We can just put that on and then say, "This profile you've been looking at for a few months is a robot." This even becomes a part of the campaign. (Interviewee 8)

Robinson (2020, pp. 5-6) expands the debate: "It's likely that different people, and possibly groups of people, generations even, have different intuitions about the authenticity and transparency requirements for online identities, and by extension, how much they are willing to trust fictional identities online." It is not clear what the real value of authenticity is in the virtual world and what other elements (attractiveness, identification, value generation, etc.) could possibly complement or even replace authenticity in online relationships with humans and nonhumans. In any case, authenticity can also be confused with a certain need for control (the more authentic, the more reliable/controllable), which requires further study.

\subsection{Controllability}

Controllability is linked to a certain predictability in relation to the influencer, which can be partially sought through contracts, among others, while also involving social media metrics (audience, engagement, conversion, etc.). A simple example is the Ipsos ranking of influencers (Metro, 2020), which pointed out the comedian Whindersson Nunes (28 million followers on YouTube) as the most well-known YouTuber in Brazil. In the same survey, the most influential YouTuber was Nathalia Arcuri ("Me Poupe" channel) at the time with "only" 4 million followers on her financial education channel. Literature states that advertising with nonhumans would be less risky (Robinson, 2020; Moustakas et al., 2020; Kádeková \& Holienčinová, 2018), but it is not clear whether the intelligence of some VIs would be more 
improved than some AIs that faced problems (Microsoft, 2016). But, in line with the literature, most interviewees agree that non-human influencers are more controllable:

For non-commercial campaigns, I think I would prioritize the virtual because I would not "risk"... If we are talking about something like philanthropy and social causes, it is very important that the people you choose have a connection with this topic, and if I choose a digital (human) influencer, I run the risk of being "betrayed" by their story on the internet. (Interviewee 2)

I think that the greater use of artificial intelligence brings many opportunities and risk forecasting is the greatest benefit. (Interviewee 3)

Also important is the autonomy of robots and artificial intelligence. There are those who call VIs "AI influencers" (Emma, 2018), perhaps anticipating a trend towards autonomy, selflearning, and self-supervision in robotics and AI, especially if combined with IoT, NLG, or machine learning, but the debate still seems immature. There are those who point to control as a greater facility to "guide" the VI, but attention must be given to another control-the social:

I initially thought about non-commercial use, so that there is education in society regarding the use of virtual influencers. Then comes commercial use. Imagine such a robot working for the alcohol industry. I think the debate will be very high and may end up hindering the entry of several other robots that could help in several other areas to share important content for society. (Interviewee 8)

Controllability also involves regulation. If regulation of advertising with human influencers already has deficiencies (Verdoodt \& Feci, 2019), there are even more uncertainties for nonhumans. A channel influencer with more than 10 million followers interviewed in this study summarizes as follows:

I, as an influencer, as we are now, is fine, but there are cases where we miss where to go. I am a huge fan of YouTube because other networks do not provide assistance. You have to fend for yourself (...) I think there is a lot of tension between authorities and companies in relation to this and we are in that limbo. I don't know what would be better for me now and for a virtual influencer I don't know either. (Interviewee 7)

The state of California (USA), for example, opted for a law to deal with robots and advertising: law SB 1001 (section 17941). It prohibits using a bot to "cheat and encourage buying or selling" or to "influence voting in an election" (California, 2018). Observing unbelievable scandals involving people of flesh and blood, perhaps robots that "look" like humans could be anything but controllable.

\subsection{Anthropomorphism/Humanization}

This category emerged from the interviews and netnography. The attribution of human characteristics to other beings (anthropomorphism) has been practiced for millennia since prehistoric rock records to "memes" with drawings on the internet involving art and religion.

There are many and growing examples of human-like robots, both physical robots such as Sophia (@realsophiarobot), and virtual robots such as Colonel Sanders/KFC (@kfc), for example.

Virtual influencers appear crying, brushing their teeth, and eating ice cream. "Are you sure you are a robot?" is not an uncommon expression in profiles such as @lilmiquela, 
@shudu.gram, @imma.gram, etc. Figure 3 show examples that many people do not know whether VIs are human or not and that this does not seem to be so decisive for their appreciation for VIs.

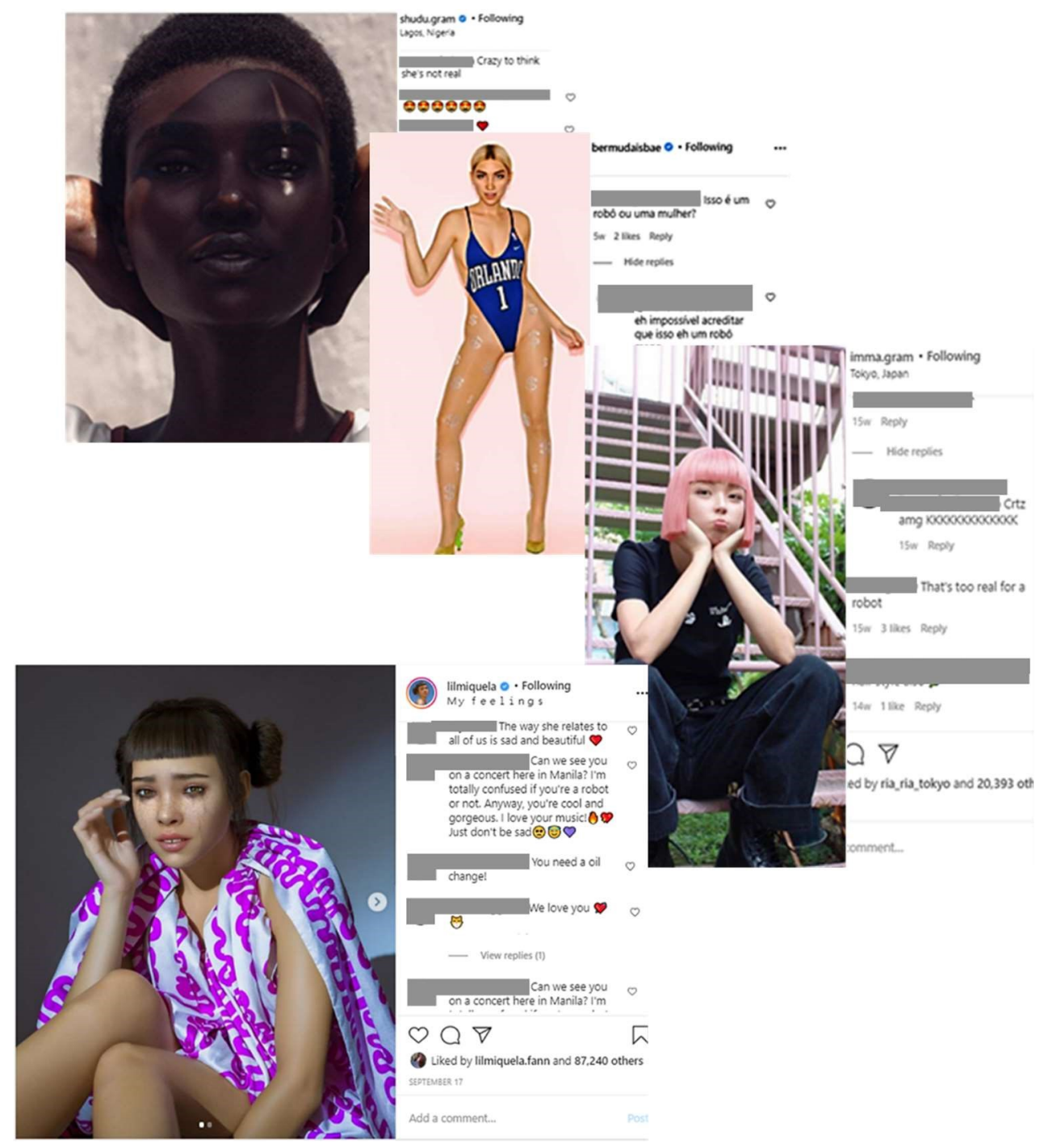

Figure 3. From left to right clockwise:

Shudu (www.instagram.com/p/CB3aQsJhKQ5/) / followers with doubts whether it would be "real" and expressions of appreciation; Bermuda (www.instagram.com/p/B9XQAFdhLB6/) / "a robot or a woman?"; Imma (www.instagram.com/p/CBkupZsjnzx/) / "too real for a robot"; Miquela (www.instagram.com/p/CFP-peqn-Z7/) / "robots cry?"

The anthropomorphism of some VIs leads many followers to ask whether the VIs are human or not, as shown in figure 3. Some are in doubt, others criticize, some defend, and there are many who, knowing or not that VIs are not human, declare appreciation, affection, support, etc.

As for Shudu, some say that it is impossible that she is not a human and the same is said about Bermuda. Imma arouses many reactions of affection and the feeling in many that she is "too real to be a robot". But VIs go beyond form or appearance with the VIs' behaviour sometimes arousing broader emotions in their followers, such as Miquela who has several fan clubs around the world. In fact, the relationship between VIs and many followers seems to have no 
difference compared to the relationship between human influencers and their flesh and blood followers, which seems to confirm the thinking of Robinson (2020) for whom VIs have no moral difference compared to human influencers.

In addition to the relational and moral dimension, affection also gains significant space in the context. For many followers, it does not seem to make much difference whether VIs are human or not. When seeing Miquela "cry", for example, a follower summarizes something valuable: "I'm totally confused if you're a robot or not. Anyway, you're cool and gorgeous. I love your music! Just don't be sad."

There are also VIs with lighter anthropomorphism that resemble a cartoon (@noonoouri, for instance). However, the focus of this study is on the most humanized VIs. In any case, consistent with the Parasocial Theory (Horton \& Wohl, 1956), an interviewee indicates concern about possible psychological impacts:

The more human the virtual influencer becomes, the more the audience will want to have personal relationships, see the show, get closer, and awaken feelings of all kinds. I think this can create confusion in the imaginary. (Interviewee 4)

Given the descriptions (Kádeková \& Holienčinová, 2018) and prescriptions (Moustakas et al., 2020) of the literature, there are those who ask "which" human is at stake:

We talk about machine learning, but it will learn what? What is the correct learning? (...) If a machine in 2016 in 24 hours has already become a neo-Nazi, imagine today, when radicalism is more acute? Look at what a danger it can become! (Interviewee 5)

Another interviewee, consistent with the Social Comparison (Miller \& Dollard, 1941) and Parasocial theories (Horton \& Wohl, 1956), expresses strong concerns about some people's mental health:

You are inspired by something that does not exist, that is manufactured-it is very cruel. (...) If we check this issue of the virtual influencer, which is more perfect and idealized, it will always be something that is so distant and perhaps the frustration is greater and can even bring more anguish and anxiety. (Interviewee 6)

Some argue, however, that anthropomorphism can generate greater identification of humans in relation to VI (Moustakas et al., 2020), which still requires further studies.

The more anthropomorphic, the more authentic (at least in theory) the virtual influencer will be. In this sense, one interviewee spoke about what would be advances and setbacks:

The challenge is to get a little out of this (...) conspiracy theory that it is a machine and is always trying to deceive me. Try to make it as human as possible. And that goes from the visual to the text and the way it interacts. And we already see some examples coming very close to this humanization, but at the same time it can be a good tool for you not to control, but to direct your audience to what you want. (Interviewee 2)

A priori, anthropomorphism is the only category in this study aimed only at robots. But the fact that some flesh and blood influencers give charity and donations after a scandal with a reduction in followers and contracts, wouldn't it be an attempt to appear more... "human"? 


\subsection{Scalability}

The questioning of the literature (Kádeková \& Holienčinová, 2018) about whether nonhumans would surpass humans (scalability) arouses non-convergent reactions in the interviewees of this study:

I think that replacing the human with a robot will still take a while, (...) but it is a trend (...) Those who do not know how to program will be out of the market (...) So, it is very important that people adapt to the scenario and start to reflect on how they will be useful in this world of virtualization, robotization, etc. We will all be teachers of robots in some way. (Interviewee 5)

Virtual influencers, in terms of productivity, would have a lot of advantages compared to human beings. (...) Imagine that dream of not having to go to sleep at 5 am, like I did yesterday, producing content? That would be incredible! (Interviewee 7)

In addition, resources such as machine learning and AI may be disruptive by attracting new markets through investors and advertisers who avoid the "unpredictability" of human influencers, for example. It is also possible that the VI is created by the brand itself, as has already been happening. These are just some of the challenges and opportunities involving virtual influencers. If a disruption via VI eventually occurs in the marketing industry, it may counteract the trend seen in other disruptions in which "former industry leaders have become irrelevant not because of their direct competitors, but because of new products and services coming from other industries" (Orlova et al., 2020, p. 1). The advance of "synthetic media" that combines CGI and artificial intelligence resources is a phenomenon on the rise (Alexander, 2019) with promising applications in marketing. In addition, in 2020, it was announced that for the first time a film will feature an artificially intelligent actor. Science fiction film $b$, with an estimated initial cost of US\$ 70 million, will have Erica, a humanoid robot (Keegan, 2020). The potential for convergence between influence, entertainment, and AI deserves attention. The feat of $\mathrm{b}$ can represent a step far beyond any work of science fiction to date.

Another sign of possible scalability to be confirmed are that the posts by Lil Miquela, the biggest virtual influencer in the world, had $224 \%$ more reach than publications by human influencers with the same number of followers in 2018 (SNPT, 2018). In 2019, VIs were almost three times more engaged than humans (HypeAuditor, 2019). It is difficult to know whether the numbers are just a "novelty effect" of the VI or other attributes. It should be noted.

\section{Theoretical and management implications}

Figure 4 presents a graphic summary with five categories (anthropomorphism /humanization, attractiveness, authenticity, scalability, and controllability) that can assist future studies and management decisions. Categories that make up the VI are dynamic and interrelated with nonlinear movements occurring between them. But these possibilities need to be tested.

This is one of the first peer-reviewed studies on virtual influencers in the world and allows us to seek more structured answers about non-human influencers, especially VIs, bringing not only the voice of specialists, but for the first time of VIs and their followers. The most relevant theoretical aspect is the addition of a new unit of analysis (non-human/VI) to the studies of digital influence, and the addition of new categories to understand this new phenomenon. Apparent certainties, such as "followers can miss the human touch" (Moustakas et al., 2020), can be questioned. In fact, in the studies by Moustakas et al. (2020), Robinson (2020), and in 
this study, most of the findings can be applied to humans and non-humans without major adjustments.

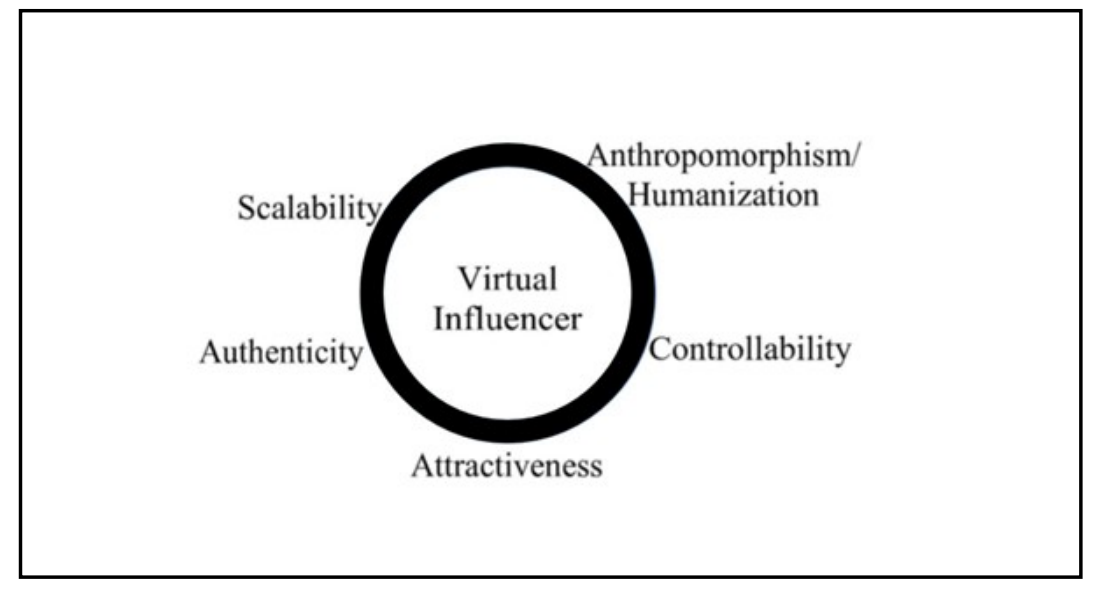

Figure 4. Categories to understand the virtual influencer phenomenon

It is possible to imagine that some sectors will have more VI representatives in the future or will prioritize VIs, especially for reasons of controllability and scalability of outsourced Vis, not to mention the possibility of customization of own VIs, time in traffic, environmental sustainability, etc. In the long run, with the advance of AI, popularization of VIs and tools to build them, scalability of VIs, control (avoiding scandals, for example), greater adherence by followers, and the development of agencies, for example, the point will come where investing in human influencers will be the basic while investing in VI will be the most advanced and even most prestigious level in some sectors. In fact, this is already happening, albeit in an embryonic way through major brands. Popularization might be a matter of time.

Thus, considering the literature review, netnography and interviews of this study, these are some managerial paths for investments in outsourced or own VIs, as shown in Table 4.

With due proportions and considering the long term, the VI may be for the human influencer as the Uber service is for the taxi service (in technology, innovation, hiring, business model, scalability, etc.). If so, arguments of some influencers will not stop the progress of VIs. It is another step towards virtualization: Kozinets $(1998 ; 1999)$ pointed to the growth of virtual communities and, later (Kozinets et al., 2010), to the network narratives of these same communities. VIs are now growing as new virtual elements with communities that surround them (followers, advertisers, fan clubs, etc.) and with narratives that emulate human appearances, interactions, and emotions or simply do not care about them. VIs are starting a form of disruption in digital marketing and especially in billionaire influencer marketing, attracting global brands to reach millions of anonymous followers who seem to have reason to seek diversification online.

Ultimately, the symbiosis between VIs and technologies such as customer service bots, robot therapists, investment bots, artificial intelligence, distance education, social network algorithms, and others can symbolize a much more complex disruption: humanity will no longer need humans for many activities and can use robots (virtual or not) for more and more possibilities ranging from sexual activities to financial investment decisions and from distance education tutoring to rock shows. This would free humanity up for several other possibilities. In fact, everyone knows that this future has already begun. It is just gaining new actors, new tools, and new memberships. And looking at it with only the eyes of the past may not be 
enough. Without preciousness or naivety, options in VIs present risks and opportunities. This study offers initial ideas (some for testing), but one of the results obtained here is that sometimes humans can be replaced by non-humans and even with more similarities or benefits than imagined. It remains to be seen whether this is advantageous.

a) Some segments (technology, fashion, etc.) seem more open to VIs, but less "obvious" segments such as food can benefit from this type of influence under some conditions.

b) In some cases, it may be necessary to make a transition before investing in VIs. As a transition between the traditional influencer (human) to the VI (non-human), one can start with cartoon-style VIs and if necessary move on to more humanized VIs. Another strategy would be to create interactions between humans and VIs. In some cases, the human can be the ideal alternative, while the non-human can be the ideal in other segments and situations.

c) Although younger generations seem more open to VIs, certain groups or niches may be more open or resistant than others within the same generation.

d) When possible, "A/B" or other tests can be used to make simultaneous announcements (one with human and one with VI, for example), comparing results and giving support to decisions.

e) In addition to the strategic aspects, the eventual decision between the VI itself or third parties requires budgetary (which is still high) and technical attention. Advanced options, such as very thought-provoking graphics and a really refined script, can only correspond to the "basics" in VI.

f) Benchmarking with companies that have invested or invest in VIs can be an interesting way to start. The formation of partnerships or groups of investors/advertisers can also dilute risks and/or costs in some cases.

g) Have you thought about an investment that reduces scandals, does not get stuck in traffic, is scalable, has an indefinite validity, and preserves the environment? The creators of some of the major VIs have also thought about these issues.

h) You will be able to meet humanized robots and robotic humans. In some situations, only one of them will deserve your attention.

i) Authenticity is relevant, but it may be less important than they usually admit. Unbelievable secrets can live near (or far) from an address called "obvious".

j) You can invest in "more of the same" (cartoons, for example) or seek innovations. Even among humans and non-humans, there may be an option to innovate. Looking at the 21st century can help you make the right choice.

k) Don't neglect the narrative (visual, textual, argumentative, etc.). If talking rats have so much power, what can humanoids with really engaging narratives do?

Table 4. Highlights on VI investments

\section{Conclusions}

This work is the beginning of a new and unpredictable journey. Inserted in a broader digitalization/virtualization context amplified by the pandemic COVID-19, some virtual influencers have resources such as realistic images, exquisite narratives, and other refinements. In an attempt to help understand this relatively recent phenomenon, this study joins the rare literature on VIs (Robinson, 2020; Moustakas et al., 2020) and is one of the first peer-reviewed studies to address virtual influencers in the world in addition to being the first to employ a systematic review of literature and netnography with VI consumers/followers and with VIs themselves. As a contribution, in addition to a wide review on digital influence, interviews were conducted with experts and agents linked to digital marketing. Three 
categories were identified from the literature (attractiveness, authenticity, and controllability) for VI analyses. Two other categories emerged from the interviews and the netnography: scalability and anthropomorphism/humanization. The five categories can interact in a nonlinear and extremely dynamic way. In the interviews of this study and in the study by Moustakas et al. (2020), a good part of the weightings of academic and market experts points to more similarities or convergences than disparities between human and non-human influencers, something that was also possible to observe via netnography.

Although the use of artificial intelligence is not so clear and the dependence on human teams is still considerable, machine learning, self-supervision, language, and other attributes of artificial intelligence have grown strongly in recent years. The Natural Language Generation (NLG) model has evolved from 1 billion parameters to 17 billion in just one year (Microsoft, 2020), for example. In addition, there are significant investments for using artificial intelligence (Alexander, 2019) and other resources to obtain differentiated results in digital marketing, including in the creation and behaviour of VIs. It should also be noted that virtualization has accelerated with the COVID-19 pandemic. In this scenario, for the reasons explained and others, the boundaries between real and virtual and between human and non-human are being reduced and presenting new realities or new concepts of reality. There are even those who say that there is nothing "morally significant" that differentiates virtual influencers from humans (Robinson, 2020).

Virtual influencers bring new scenarios to digital marketing and more. If most analyses (including this study) point to more convergence than divergence between real and virtual and between human and non-human, then of the two, one: 1) it is necessary to change the analytical structure or 2) there is a way for influential robots with an increasingly "human, too human" (Nietzsche 1908/1878) touch. The second option would be a good one. Or not?

\section{Limitations and future research}

This study is exploratory and does not seek to establish generalizations or quantify causal relationships between variables, its research design does not allow statistical analysis, and the criteria used to select VI profiles in the netnography is a limitation. As it reproduces the top five of a world ranking, there is a risk of selection bias. Less expressive profiles may have attributes not identified in this study, so the profiles selected may not represent the entire spectrum of VI characteristics and future investigations should include different profiles.

Regarding future work, the phenomenon allows multiple approaches, methods, and fields of study. Building upon the categories identified in this paper, future studies can investigate more deeply how and why people get involved with VI. In addition, they can assess the implications of different types of VI on various aspects such as consumption, work, behaviour, and social (and/or para-social) relationships. Various comparisons between humans and VI can be undertaken and involve everything from traits such as empathy to performance (engagement, conversion). One of the central studies for the management/marketing area would be analysing the managerial implications of reputation and performance with a focus on the performance of VIs in conversion/sales. Studies on technique, graphics, autonomy, and the use of artificial intelligence to improve VI (in addition to ethical, philosophical, and legal aspects) also have strong research potential. Finally, issues such as complementarity and eventual replacement of humans by non-humans (Kádeková \& Holienčinová, 2018) are crucial and can be researched from different perspectives ranging from marketing to public policies. 


\section{References}

Alexander, J. (2019). Virtual creators aren't AI - but AI is coming for them. The Verge. theverge.com/2019/1/30/18200509/ai-virtual-creators-lil-miquela-instagram-artificialintelligence

Appel, G., Grewal, L., Hadi, R., \& Stephen, A. T. (2020). The future of social media in marketing. Journal of the Academy of Marketing Science, 48, 79-95. https://doi.org/10.1007/s11747-019-00695-1

Aran-Ramspott, S., Fedele, M., \& Tarragó, A. (2018). Youtubers' social functions and their influence on pre-adolescence. Media Education Research Journal, 26(57), 71-79. https://doi.org/10.3916/C57-2018-07

Archer, C., \& Harrigan, P. (2016). Prosumers with passion: Learning what motivates bloggers as digital influencer stakeholders. PRism, 13(1), 1-14. www.prismjournal.org/ uploads/1/2/5/6/125661607/v13-no1-a4.pdf

Ashman, R., Patterson, A., \& Brown, S. (2018). 'Don't forget to like, share and subscribe': Digital autopreneurs in a neoliberal world. Journal of Business Research, 92, 474-483. https://doi.org/10.1016/j.jbusres.2018.07.055

Association of National Advertisers. (2018). Survey report: How ANA members are using influencer marketing. https://www.ana.net/getfile/26389

Belk, R., Fisher, E., \& Kozinets, R. Qualitative consumer and marketing research. London: Sage, 2013.

Boerman, S. C. (2020). The effects of the standardized instagram disclosure for micro- and mesoinfluencers. Computers in Human Behavior, 103, 199-207. https://doi.org/10.1016/ j.chb.2019.09.015

Bond, B. (2016). Following Your "Friend": Social Media and the Strength of Adolescents' Parasocial Relationships with Media Personae. Cyberpsychology, Behavior, and Social Networking, 19(11), 656-660. https://doi.org/10.1089/cyber.2016.0355

California. (2018). Senate Bill No 1001. An act to add Chapter 6 (commencing with Section 17940) to Part 3 of Division 7 of the Business and Professions Code, relating to bots. Approved September 28. California Legislative Information. http://leginfo.legislature.ca.gov/faces/billTextClient.xhtml?bill_id=201720180SB1001

Carvalho, G. J. (2018). Social networks and digital influences: A description of the influences in the digital consumer behavior. PMKT - Brazilian Journal of Marketing Research, Opinion and Media, 11(3), 277-288. http://www.revistapmkt.com.br/Portals/9/Revistas/ v11n3/engb/4Social\%20networks\%20and\%20digital\%20influences $\% 20 \mathrm{~A} \% 20$ description \%20of $\% 20$ the \%20influences\%20in\%20the\%20digital\%20consumer\%20behavior.pdf

Casaló, L. V., Flavián, C., \& Ibáñez-Sánchez, S. (2020). Influencers on Instagram: Antecedents and consequences of opinion leadership. Journal of Business Research, 217, 510-519. https://doi.org/10.1016/j.jbusres.2018.07.005

Clifford, D., \& Verdoodt, V. (2017). Integrative advertising: the marketing 'dark side' or merely the emperor's new clothes? European Journal of Law and Technology, 8(1), 1-43. researchgate.net/publication/316101961 
Cotter, K. (2018). Playing the visibility game: How digital influencers and algorithms negotiate influence on Instagram. New Media \& Society, 21(4), 895-913. https://doi.org/10.1177/1461444818815684

Creswell, J., \& Miller, D. (2000). Determining Validity in Qualitative Inquiry. Theory into Practice, 39(3), 124-130. https://doi.org/10.1207/s15430421tip3903_2

Dobreva, D., Grinnell, D., \& Innes, M. (2019). Prophets and Loss: How "Soft Facts" on Social Media Influenced the Brexit Campaign and Social Reactions to the Murder of Jo Cox MP. Policy \& Internet, 12(2), 144-164. https://doi.org/10.1002/poi3.203

Drenten, J., Gurrieri, L., \& Tyler, M. (2020). Sexualized labour in digital culture: Instagram influencers, porn chic and the monetization of attention. Gender Work Organ, 27(1), 4166. https://doi.org/10.1111/gwao.12354

Edgerton, E., Reiney, E., Mueller, S., Reicherter, B., Curtis, K., Waties, S., \& Limber, S. P. (2016). Identifying New Strategies to Assess and Promote Online Health Communication and Social Media Outreach. Health Promotion Practice, 17(3), 448-456. www.jstor.org/stable/10.2307/26734036

Emma, R. (2018). The Rise of the Virtual Influencers. Influencer. https://blog.influencer.uk/therise-of-virtual-influencers-1fdb0c13907f

Flanagan, J. C. (1954). The Critical Incident Technique. Psychological Bulletin, 51(4). https://www.apa.org/pubs/databases/psycinfo/cit-article.pdf

Gillpatrick, T. (2019). The Digital Transformation of Marketing: Impact on Marketing Practice \& Markets. Economics, 7(2), 139-156. https://doi.org/10.2478/eoik-2019-0023

Gillpatrick, T., Blunck, E., \& Boğa, S. (2019). Understanding the role of consumer behavior in forecasting the impact of industry 4.0 and the wave of digital disruption driving innovation in retailing. Dubrovnik International Economic Meeting, 4(1), 165-176. hrcak.srce.hr/228708

GlobalWebIndex. (2019). Global Web Index Social Media Report. https://www.globalwebindex.com/reports?page_num=10

Goanta, C., (2018). How Technology Disrupts Private Law: An Exploratory Study of California and Switzerland as Innovative Jurisdictions. Stanford-Vienna Transatlantic Technology Law Forum, 38, 1-53. https://law.stanford.edu/publications/no-38-how-technologydisrupts-private-law-an-exploratory-study-of-california-and-switzerland-asinnovative-jurisdictions/

Golder, S. A., \& Macy, M. W. (2014). Digital Footprints: Opportunities and Challenges for Online Social Research. Annual Review of Sociology, 40, 129-152. www.jstor.org/stable/ 43049529

Graziano, D. C., \& Perez, G. (2018). The Impact of The Internet on the E-Commerce Organizations. Journal of Financial Innovation, 1-13. www.researchgate.net/publication/ 330015305

Gross, J., \& Wangenheim, F. V. (2018). The Big Four of Influencer Marketing. A Typology of Influencers. Marketing Review St. Gallen, 2, 30-38. https://papers.ssrn.com/sol3/ papers.cfm?abstract_id=3230687 
Guerreiro, C., Viegas, M., \& Guerreiro, M. (2019). Social networks and Digital influencers: their role in customer decision journey in tourism. Journal of Spatial and Organizational Dynamics, 7(3), 240-260. www.jsod-cieo.net/journal/index.php/jsod/article/view/198

Hasan, H., \& Linger, H. (2020). Letting the public in: dialectic tensions when local governments move beyond e-government to e-democracy. Australasian Journal of Information Systems. Vol. 24, https://doi.org/10.3127/ajis.v24i0.1897

Horton, D., \& Wohl, R. R. (1956). Mass Communication and Para-Social Interaction, Psychiatry, 19(3), 215-229. https://doi.org/10.1080/00332747.1956.11023049

Hutchinson, J. (2019). Digital first personality: Automation and influence within evolving media ecologies. Convergence, 26(5-6), 1284-1300. https://doi.org/10.1177/ 1354856519858921

HypeAuditor. (2019). The top Instagram virtual influencers in 2019. https://hypeauditor.com/blog/the-top-instagram-virtual-influencers-in-2019/

Jiménez-Castillo, D., \& Sánchez-Fernández, R. (2019). The role of digital influencers in brand recommendation: Examining their impact on engagement, expected value and purchase intention. International Journal of Information Management, 49, 366-376. https://doi.org/10.1016/j.ijinfomgt.2019.07.009

Jorge, A., Marôpo, L., \& Nunes, T. (2018). 'I am not being sponsored to say this': a teen youtuber and her audience negotiate branded content. Observatorio. Special issue on The co-option of audiences in the attention economy. https://doi.org/10.15847/ obsOBS0001382

Kádeková, Z., \& Holienčinová, M. (2018). Influencer marketing as a modern phenomenon creating a new frontier of virtual opportunities. Communication Today, 9(2), 90-104. www.researchgate.net/publication/329247338

Kautz, K., Bjerknes, G., Fisher, J., \& Jensen, T. (2020). Applying Complex Adaptive Systems Theory to Understand Distributed Participatory Design in Contemporary, Crowdsourced Information Systems Development. Australasian Journal of Information Systems. Vol. 24, Selected Papers from ACIS 2018. https://doi.org/10.3127/ajis.v24i0.2225

Keegan, R. (2020). A.I. Robot Cast in Lead Role of \$70M Sci-Fi Film. The Hollywood Reporter. www.hollywoodreporter.com/news/ai-robot-cast-lead-role-70m-sci-fi-film-1300068

Kozinets, R. V. (1998, November 9). How Online Communities Are Growing in Power. Financial Times, 291-96.

Kozinets, R. V. (1999). E-tribalized marketing: the strategic implications of virtual communities of consumption. European Management Journal, 17(3), 252-264. https://doi.org/10.1016/S0263-2373(99)00004-3

Kozinets, R. V. (2002). The Field Behind the Screen: Using Netnography for Marketing Research in Online Communities. Journal of Marketing Research, 39(1), 61-72. https://doi.org/10.1509/jmkr.39.1.61.18935

Kozinets, R. V. (2015). Netnography: Redefined. London: Sage. 
Kozinets, R. V. (2019). YouTube utopianism: Social media profanation and the clicktivism of capitalist critique. Journal of Business Research, 98, 65-81. https://doi.org/10.1016/j.jbusres.2019.01.019

Kozinets, R. V., De Valck, K., Wojnicki, A. C., \& Wilner, S. J. S. (2010). Networked Narratives: Understanding Word-of-Mouth Marketing in Online Communities. Journal of Marketing, 74(2), 71-89. https://www.researchgate.net/publication/255600900

Kozinets, R. V., \& Nocker, M. (2018). Netnography: Online ethnography for a digital age of organization research. In A. Bryman, \& D. A. Buchanan (Eds.). Unconventional methodology in organization and management research (pp. 127-146). Cambridge, UK: Oxford University Press.

Kuksov, D., \& Liao, C. (2019). Opinion Leaders and Product Variety. Marketing Science, 38(5), 812-834. https://doi.org/10.1287/mksc.2019.1179

MacInnis, D. J., Morwitz, V. G., Botti, S., Hoffman, D. L., Kozinets, R. V., Lehmann, D. R., Lynch, J. G., \& Pechmann, C. (2020). Creating Boundary-Breaking, Marketing-Relevant Consumer Research. Journal of Marketing, 84(2), 1-23. https://doi.org/10.1177/0022242919889876

Maden, D. (2018). The Role of Digital Influencers in the Diffusion of New Products. Akdeniz Üniversitesi İletişim Fakültesi Dergisi, 30, 119-141. https://doi.org/10.31123/akil.465923

Marôpo, L., Jorge A., \& Tomaz, R. (2020). “I felt like I was really talking to you!”: intimacy and trust among teen vloggers and followers in Portugal and Brazil, Journal of Children and Media, 14(1), 22-37. https://doi.org/10.1080/17482798.2019.1699589

McLuhan, M. \& Fiore, Q. (1967). The Medium is the Massage: An Inventory of Effects. New York: Random House.

Metro. (2020). Pesquisa aponta Evaristo Costa como maior 'influencer' do Brasil (Research appoints Evaristo Costa as the greatest 'influencer' in Brazil). Metrojornal. metrojornal.com.br/entretenimento/2020/02/17/evaristo-costa-maior-influencerbrasil.html

Microsoft. (2016). Learning from Tay's introduction. Peter Lee (Corporate Vice President). Official Microsoft Blog. https://blogs.microsoft.com/blog/2016/03/25/learning-taysintroduction/\#sm.00000gjdpwwcfcus11t6oo6dw79gw

Microsoft. (2020). Microsoft announces new supercomputer, lays out vision for future AI work. Jennifer Langston. The Official Microsoft Blog. https://blogs.microsoft.com/ ai/openai-azure-supercomputer/

Miles, M. B., Huberman, A. M., \& Saldaña, J. (2014). Qualitative Data Analysis: A Methods Sourcebook. Thousand Oaks, CA: SAGE, 2014. 381 pp.

Miller, N. E., \& Dollard, J. (1941). Social Learning and Imitation. New Haven: Yale University Press. https://doi.org/10.1177/00027162422200019

Miranda, S., Cunha, P., \& Duarte, M. (2019). An integrated model of factors affecting consumer attitudes and intentions towards youtuber-generated product content. Review of Managerial Science. https://doi.org/10.1007/s11846-019-00370-3 
Moura, B. S. (2019). Relationship Marketing in Social Networks for Small Businesses. PMKT Brazilian Journal of Marketing Research, Opinion and Media, 12(1), 46-62. revistapmkt.com.br/Portals/9/Revistas/v12n1/en-gb/5\%20-

\%20Relationship\%20Marketing\%20in\%20Social\%20Networks\%20for\%20Small\%20Busi nesses.pdf

Moustakas, E., Lamba, N., Mahmoud, D., \& Ranganathan, C. (2020). Blurring lines between fiction and reality: Perspectives of experts on marketing effectiveness of virtual influencers. Social Media Conference IEEE. International Journal on Cyber Situational Awareness. https://doi.org/10.22619\%2FIJCSA

Nietzsche, F. (1908). Human, all too human - A book for free spirits (Alexander Harvey, Ed. \& Trans.). Charles H. Kerr \& Company. (Original work published 1878). https://www.gutenberg.org/files/38145/38145-h/38145-h.htm

Orlova, A., Nogueira, R. \& Chimenti, P. (2020). The Present and Future of the Space Sector: A Business Ecosystem Approach. Space Policy, 52, 1-8. https://doi.org/10.1016/j.spacepol.2020.101374

Robinson, B. (2020). Towards an Ontology and Ethics of Virtual Influencers. Australasian Journal of Information Systems, 24, 1-8. https://doi.org/10.3127/ajis.v24i0.2807

Silva, M. J. B., Farias, S. A., Grigg, M. K., \& Barbosa, M. L. A. (2020). Online Engagement and the Role of Digital Influencers in Product Endorsement on Instagram. Journal of Relationship Marketing, 19(2), 133-163. https://doi.org/10.1080/15332667.2019.1664872

SNPT. (2018). https://www.getsnapppt.com/blog/can-artificial-influencers-replace-humans

Torres, P., Augusto, M., \& Matos, M. (2019). Antecedents and outcomes of digital influencer endorsement: An exploratory study. Psychology \& Marketing, 36(12), 1267-1276. https://doi.org/10.1002/mar.21274

Verdoodt, V., \& Feci, N. (2019). Digital influencers and vlogging advertising: Calling for awareness, guidance and enforcement. Larcier. Auteurs en Media, 1, 11-22. https://limo.libis.be/primoexplore/fulldisplay?docid=LIRIAS2339326\&context=L\&vid= Lirias\&search_scope=Lirias\&tab=default_tab\&lang=en_US\&fromSitemap $=1$

Vinerean, S. (2017). Importance of Strategic Social Media Marketing. Expert Journal of Marketing, 5(1), 28-35. http://marketing.expertjournals.com/23446773-504/ \#: :text=Nowadays\%2C\%20social\%20media\%20has\%20developed,to\%20instigate\%20c ustomer\%2Dto\%2Dcustomer

Copyright: () 2021 authors. This is an open-access article distributed under the terms of the Creative Commons Attribution-NonCommercial 3.0 Australia License, which permits noncommercial use, distribution, and reproduction in any medium, provided the original author and AJIS are credited. 
doi: https://doi.org/10.3127/ajis.v25i0.3223

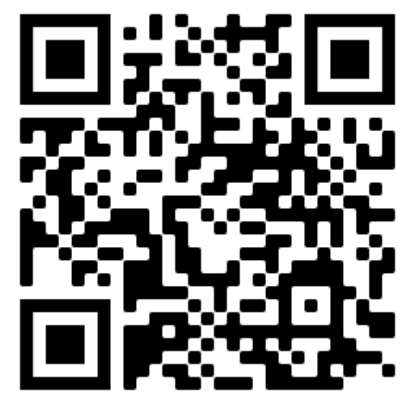

